\begin{tabular}{lcc}
\hline \multicolumn{3}{c}{ ANNALES } \\
UNIVERSITATIS MARIAE CURIE-SKŁODOWSKA & \\
LOL. LXXI, 1 & SECTIO AA & 2016 \\
\hline
\end{tabular}

\title{
Stability of technetium in the moderate oxidation states in acidic media
}

\author{
Maciej Chotkowski ${ }^{\mathrm{a}}$ and Andrzej Czerwiński ${ }^{\mathrm{a}, \mathrm{b}, *}$ \\ ${ }^{a}$ University of Warsaw, Faculty of Chemistry, 02-927 Warsaw, Poland \\ ${ }^{b}$ Industrial Chemistry Research Institute, Department of Electrochemistry \\ Rydygiera 8, 01 - 793 Warsaw, Poland \\ e-mail: aczerw@chem.uw.edu.pl
}

Technetium is one of the most important radionuclides in the spent nuclear fuel in context of reprocessing, storage and long term disposal. Spectroelectrochemical studies on the redox behavior of this element are presented and possible pathways of pertechnetate ions reduction are discussed. The stability of technetium (III/IV) species are discussed.

\section{INTRODUCTION}

In an era of nuclear power development, one of the most important factor of nuclear power plant safety is the waste security and their protection against the migration of radioactive elements to the environment. From this point of view the long lived radionuclides are especially hazardous. One of them is technetium-99. This radioisotope is one of the major nuclear fission products. His half-life equals $213000 \mathrm{y}$ [1] and due to the fact that technetium exists in aerobic environment as high mobile pertechnetate ions, it poses a threat to the health of living organisms [2]. It is possible to reduce $\mathrm{TcO}_{4}{ }^{-}$to technetium dioxide but unfortunately $\mathrm{TcO}_{2}$ can be relatively easy reoxidized to pertechnetates.

The literature presents different views on the process of pertechnetate reduction [3]. The observed inconsistencies can be related not only to the 
influence of supporting electrolytes in which the electrochemical experiments are carried out but also to the effect of the electrode material on the redox reaction of technetium compounds. This phenomena was presented in our previous paper [4].

The difficulties in determining the products of pertechnetate ions electroreduction appear at the first step of discussed process. In acidic media not only technetium trioxide [5] but also technetates(VI) [6] are postulated as the substances adsorbed or deposited on the electrode:

$$
\begin{gathered}
\mathrm{TcO}_{4}{ }^{-}+2 \mathrm{H}^{+}+\mathrm{e}^{-} \rightarrow \mathrm{TcO}_{3} \\
\mathrm{TcO}_{4}{ }^{-}+\mathrm{H}^{+}+\mathrm{e}^{-} \rightarrow \mathrm{HTcO}_{4}{ }^{-}
\end{gathered}
$$

The situation is further complicated by the fact that $\mathrm{Tc}(\mathrm{VI})$ and $\mathrm{Tc}(\mathrm{V})$ are not stable and disproportionate:

$$
2 \mathrm{HTcO}_{4}{ }^{-}+4 \mathrm{H}^{+} \rightarrow \mathrm{TcO}_{4}{ }^{-}+\mathrm{TcO}^{3+}+3 \mathrm{H}_{2} \mathrm{O}
$$

or

$$
2 \mathrm{TcO}_{3}+2 \mathrm{H}^{+} \rightarrow \mathrm{TcO}_{4}{ }^{-}+\mathrm{TcO}^{3+}+\mathrm{H}_{2} \mathrm{O}
$$

As a product of these chemical steps technetium(IV) ions are generated:

$$
2 \mathrm{TcO}^{3+}+3 \mathrm{H}_{2} \mathrm{O} \rightarrow \mathrm{HTcO}_{4}{ }^{-}+\mathrm{TcO}^{2+}+5 \mathrm{H}^{+}
$$

The existence of $\mathrm{TcO}^{3+}$ was confirmed in $13 \mathrm{M} \mathrm{H}_{2} \mathrm{SO}_{4}$ by EXAFS analyses [7]. $\mathrm{Tc}(\mathrm{V})$ solutions absorb light in the red region of the spectrum $\left(\lambda_{\max }=695 \mathrm{~nm}, \varepsilon=33 \mathrm{M} \mathrm{cm}^{-1}\right)$ and from this reason UV-Vis spectroscopy can be used to determine the behavior of this technetium form.

In strongly concentrated sulfuric acid solutions pertechnetates convert into $\mathrm{TcO}_{3}{ }^{+}$. As a results of these structural changes the evolution of UV-VIS spectrum is observed. The characteristic for pertechnetates ions bands at $244 \mathrm{~nm}$ and $287 \mathrm{~nm}$ are shifted toward longer wavelengths values $255 \mathrm{~nm}$ and $329 \mathrm{~nm}$ [8].

The structures of technetium(IV) compounds strongly depend on the acidity of the solution. $\mathrm{TcO}^{2+}$ are observed and relatively stable in $4 \mathrm{M}$ $\mathrm{H}_{2} \mathrm{SO}_{4}$ and can be characterized spectroscopically by the band at $400 \mathrm{~nm}$ [9]. The decrease of the solution acidity results in transformation of monooxotechnetium(IV) to oxohydroxotechnetium(IV)[3]:

$$
\begin{array}{ll}
\mathrm{TcO}^{2+}+\mathrm{H}_{2} \mathrm{O}=\mathrm{TcO}(\mathrm{OH})^{+}+\mathrm{H}^{+} & \log _{10} \mathrm{~K}=-1.37 \\
\mathrm{TcO}(\mathrm{OH})^{+}+\mathrm{H}_{2} \mathrm{O}=\mathrm{TcO}(\mathrm{OH})_{2} & \log _{10} \mathrm{~K}=-2.43
\end{array}
$$


$\mathrm{TcO}(\mathrm{OH})_{2}$ is recommended as the reference species and a major product of $\mathrm{TcO}_{4}{ }^{-}$ions electroreduction in non-complexing solutions between $\mathrm{pH} 2$ and 10:

$$
\mathrm{TcO}_{4}{ }^{-}+4 \mathrm{H}^{+}+3 \mathrm{e}^{-} \rightarrow \mathrm{TcO}(\mathrm{OH})_{2}+\mathrm{H}_{2} \mathrm{O} \quad \mathrm{E}^{0}=0.579 \mathrm{~V}
$$

Except $\mathrm{TcO}(\mathrm{OH})_{2}$ also $\mathrm{TcO}_{2} \bullet \mathrm{xH}_{2} \mathrm{O}$ can be generated in acidic media but the standard reduction potential related to this technetium(IV) form is much higher than for dihydroxooxotechnetium(IV):

$$
\mathrm{TcO}_{4}{ }^{-}+4 \mathrm{H}^{+}+3 \mathrm{e}^{-} \rightarrow \mathrm{TcO}_{2} \cdot \mathrm{xH}_{2} \mathrm{O}+(2-\mathrm{x}) \mathrm{H}_{2} \mathrm{O} \quad \mathrm{E}^{0}=0.746 \mathrm{~V}
$$

Species described above do not exhaust the list of possible structures of Tc(IV)-O compounds.

Much more stable than $\mathrm{TcO}^{2+}$ in acidic solutions are dimeric $[\mathrm{Tc}(\mu-$ $\left.\mathrm{O}_{2} \mathrm{Tc}\right]^{3 / 4+}$ or polioxopolimetallic, $\mathrm{Tc}_{3} \mathrm{O}_{4}{ }^{4+}$, ions [10]. These ions are characterized spectroscopically by the band at $502 \mathrm{~nm}$. Noteworthly is the fact that $\mathrm{Tc}\left(\mathrm{III} / \mathrm{IV}\right.$ or IV) are generated not only as the products of $\mathrm{TcO}_{4}{ }^{-}$ electroreduction in the potential range $0.3-0.5 \mathrm{~V}$ [4] but also during electroplating of metallic technetium from $1 \mathrm{M} \mathrm{H}_{2} \mathrm{SO}_{4}+\mathrm{NH}_{4} \mathrm{TcO}_{4}$ [11]. Observed phenomena indicates that $\left[\mathrm{Tc}(\mu-\mathrm{O})_{2} \mathrm{Tc}\right]^{3 / 4+}$ or $\mathrm{Tc}_{3} \mathrm{O}_{4}{ }^{4+}$ ions can be generated in the synproportionation reaction between technetium with lower oxidation states, e.g. Tc(III) or even Tc(II) and Tc(VII). Regardless the possible mechanism of dimeric and/or polymeric technetium(III/IV) species formation, these ions are relatively stable in aqueous media $[9,12]$ even in the presence of nitric acid [13].

Our earlier investigations showed that $\left[\mathrm{Tc}(\mu-\mathrm{O})_{2} \mathrm{Tc}\right]^{3+}$ can be reduced to Tc(III) [4] according to:

$$
\left[\mathrm{Tc}(\mu-\mathrm{O})_{2} \mathrm{Tc}\right]^{3+}+2 \mathrm{H}_{2} \mathrm{O}+\mathrm{e}^{-} \rightarrow 2 \mathrm{TcO}(\mathrm{OH})+2 \mathrm{H}^{+}
$$

The standard redox potential of this reaction equals $0.512 \mathrm{~V}$ vs. SHE.

In sulfuric [10] or nitric [14] acid solutions also Tc(III) ionic species were identified. $\mathrm{Tc}^{3+}$ or $\mathrm{TcO}^{+}$ions (till now the structure is unknown) are characterized spectroscopically by visible band at $440 \mathrm{~nm}$ and can be distinguished from oxotechnetium(IV) showing a band with a maximum at $400 \mathrm{~nm}$.

\section{EXPERIMENTAL}

A home made optically transparent thin layer cell based on reticulated vitreous carbon (RVC-OTTL) (thickness $2 \mathrm{~mm} ; 100$ ppi porosity) (ERG 
Aerospace Corporation) as a working electrodes was used to perform spectroelectrochemical experiments [15-17]. A standard $\mathrm{Ag} / \mathrm{AgCl}$ electrode was used as a reference electrode, but all the potentials presented in the text are referred to SHE.

The solutions were prepared using high purity chemicals: potassium pertechnetate, $\mathrm{K}^{99} \mathrm{TcO}_{4}$ (obtained from Forschungszentrum DresdenRossendorf - Institute of Radiopharmacy), sulfuric and nitric acids, (POCh, Poland) and high purity distilled water (Millipore ${ }^{\circledR}$ ) All measurements were performed at $298 \mathrm{~K}$, the solutions were deoxyganted with $\operatorname{Ar}(4 \mathrm{~N})$. The electrochemical and spectroscopic measurements were performed simultaneously using MultiSpec 1500 (Shimadzu) spectrophotometer and CHI604 (CH Instruments) electrochemical analyzer, respectively.

\section{RESULTS AND DISCUSSION}

Fig. 1 presents typical cyclic voltammograms recorded for glassy carbon (GC), platinum ( $\mathrm{Pt}$ ) and gold ( $\mathrm{Au}$ ) electrodes in $4 \mathrm{M} \mathrm{H}_{2} \mathrm{SO}_{4}$ with an additional of $0.5 \mathrm{mM} \mathrm{KTcO}_{4}$. Currents due to to first step reduction of pertechnetates especially visible for gold electrode in $4 \mathrm{M} \mathrm{H}_{2} \mathrm{SO}_{4}$ starts at ca. $0.9 \mathrm{~V}$. For platinum cathodic currents starts at potentials even higher $($ ca. $+1 . \mathrm{V})$ but they can be attributed not only to $\mathrm{TcO}_{4}{ }^{-}$electroreduction but mainly to reduction of platinium oxides presented on the surface of the electrode [18]. This assymetrical peak is observed in the potential range of $0.4-1 \mathrm{~V}$. Noteworthly is the fact that currents due to the adsorption/desorption of hydrogen which are typical for platinum in technetium ,free” sulfuric acid solutions at potentials lower than $0.4 \mathrm{~V}$ are not observed.

The efficiency of pertechnetates reduction is the lowest for glassy carbon electrodes. For this electrode material only weak increase of currents is observed at potentials lower than $0.65 \mathrm{~V}$. The influence of the acid concentration on cyclic voltammograns recorded for 1,2 and $4 \mathrm{M}$ $\mathrm{H}_{2} \mathrm{SO}_{4}$ discussed in our earlier paper [9] is especially visible for gold. An increase in acid concentration significantly affects first electreduction peak connected with reduction of $\mathrm{Tc}(\mathrm{VII})$ to $\mathrm{Tc}(\mathrm{IV})$ via unstable $\mathrm{Tc}(\mathrm{VI})$ and $\mathrm{Tc}(\mathrm{V})$ forms. This peak shifts from $0.78 \mathrm{~V}$ for $1 \mathrm{M} \mathrm{H}_{2} \mathrm{SO}_{4}$ to $0.87 \mathrm{~V}$ for $4 \mathrm{M} \mathrm{H}_{2} \mathrm{SO}_{4}$ and becomes more intense. The second broad and misshapen cathodic wave seen at lower potentials $(0-0.6 \mathrm{~V})$ is due to various electrochemical and chemical steps of technetium compounds 
with various oxidation states - electroreduction of pertechnetates to technetium(III), electroreduction of dimeric or polyoxometallic technetium(IV) to technetium (III) or eventually synproportionation of $\mathrm{Tc}$ (III) with pertechnetates(VII). At potentials near $0.2 \mathrm{~V}$ the generation of unstable technetium(II) ions can not be excluded and also an additional possible chemical reactions involved these ions should be consider.

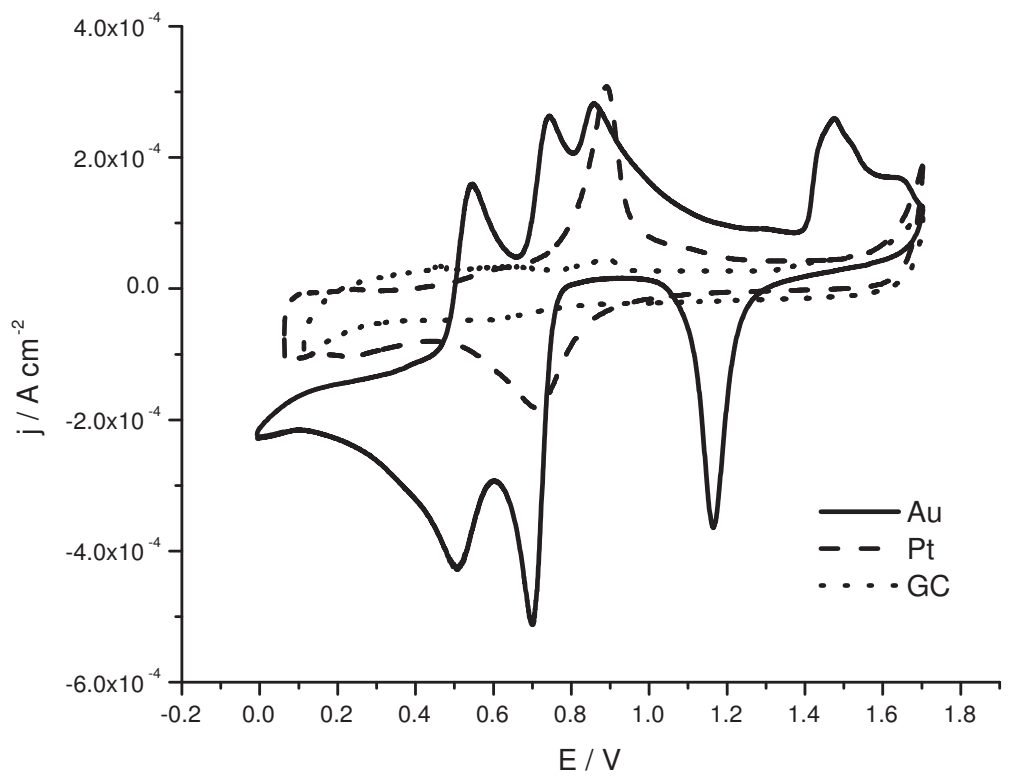

Fig. 1. Cyclic voltammograms of gold, platinum and glassy carbon electrodes in $1.1 \mathrm{mM} \mathrm{KTcO}_{4}$ and $4 \mathrm{M} \mathrm{H}_{2} \mathrm{SO}_{4}, v=50 \mathrm{mV} / \mathrm{s}$.

In anodic branch of cyclic voltammogram for platinum revelas a broad electrooxidation peak at potential of $0.87 \mathrm{~V}$. According to the literature, which described various rhenium compounds: $\mathrm{ReO}_{2}, \mathrm{ReO}_{3}$ or even $\mathrm{Re}_{2} \mathrm{O}_{5}$ deposited during electroreduction of perrhenate ions [19], also for technetium should be expected species with various valence states which are electrooxidated to pertechnetates.

Anodic section of voltammetric curves recorded for $\mathrm{Au}$ electrodes reveals three, partially overlapped, oxidation peaks. The first peak observed at ca. $0.55 \mathrm{~V}$ can be attributed to the oxidation of $\mathrm{Tc}(\mathrm{III})$ to $\mathrm{Tc}(\mathrm{III} / \mathrm{IV})$ and/or to Tc(IV). A poor shaped middle peak can be attributed to electroxidation of $\mathrm{TcO}^{2+}$ or polymeric $\mathrm{Tc}(\mathrm{IV})$ to $\mathrm{Tc}(\mathrm{VII})$. The most anodic one of all three peaks observed at $0.85 \mathrm{~V}$ can be linked with electrooxidation of especially stable dimeric technetium(III/IV) to pertechnetates. This peak is the highest not only for $4 \mathrm{M} \mathrm{H}_{2} \mathrm{SO}_{4}$ but also for lower sulfuric acid concentrations, as was reported in our earlier paper 
[9], which indicates transformation of other technetium (III or IV, e.g. $\left.\mathrm{Tc}^{3+}, \mathrm{TcO}^{+}, \mathrm{TcO}^{2+}\right)$ species into the $\left[\mathrm{Tc}(\mu-\mathrm{O})_{2} \mathrm{Tc}\right]^{3+}$.

The transformation of technetium(III) ions into dimeric or polymeric structures of Tc(III,IV or IV) was confirmed by spectroelectrochemical experiments. Figure 2 presents $\mathrm{UV}$-vis spectra recorded after chronoamperometric polarization of RVC-OTTLE in $0.5 \mathrm{mM} \mathrm{KTcO}_{4}+4$ $\mathrm{M} \mathrm{H}_{2} \mathrm{SO}_{4}$, at potential $0.35 \mathrm{~V}$.



Fig. 2. UV-Vis spectra recorded after the end of chronoamperometric polarization of RVC-OTTLE in $0.5 \mathrm{mM} \mathrm{KTcO}_{4}+4 \mathrm{M} \mathrm{H}_{2} \mathrm{SO}_{4}$ at potential $+0.35 \mathrm{~V}$.

UV-Vis spectra recorded after polarization at $0.35 \mathrm{~V}$ presents technetium (III) species characterized spectroscopically by the band at $440 \mathrm{~nm}$. The transformation/oxidation of these ions taking place at $60^{\circ} \mathrm{C}$ within $10 \mathrm{~h}$ followed by keeping the cell under open circuit potential reveals waves with maxima at $502 \mathrm{~nm}$ and $320 \mathrm{~nm}$ without signal characteristic for $\mathrm{Tc}(\mathrm{III})$ species. The band at $320 \mathrm{~nm}$ corresponds to a molecular electronic transition of polymeric Tc(IV) species [20] while the band at $502 \mathrm{~nm}$ can be attributed to dimeric structure of Tc(III/IV) [21]. The electrochemical properties of both discussed species differ.

The technetium(IV) species are oxidized at potentials lower than $0.7 \mathrm{~V}$ while dimeric Tc(III,IV) structures at these potentials are stable, Fig. 3. These results are in line with cyclic votammograms (Fig. 1) where the middle anodic peak was attributed to electrooxidation of Tc(IV) species 
to pertechnetates. The intensity of the band at $320 \mathrm{~nm}$ decreases significantly and characteristic for $\mathrm{TcO}_{4}{ }^{-}$ions two bands at $244 \mathrm{~nm}$ and $287 \mathrm{~nm}$ appears.

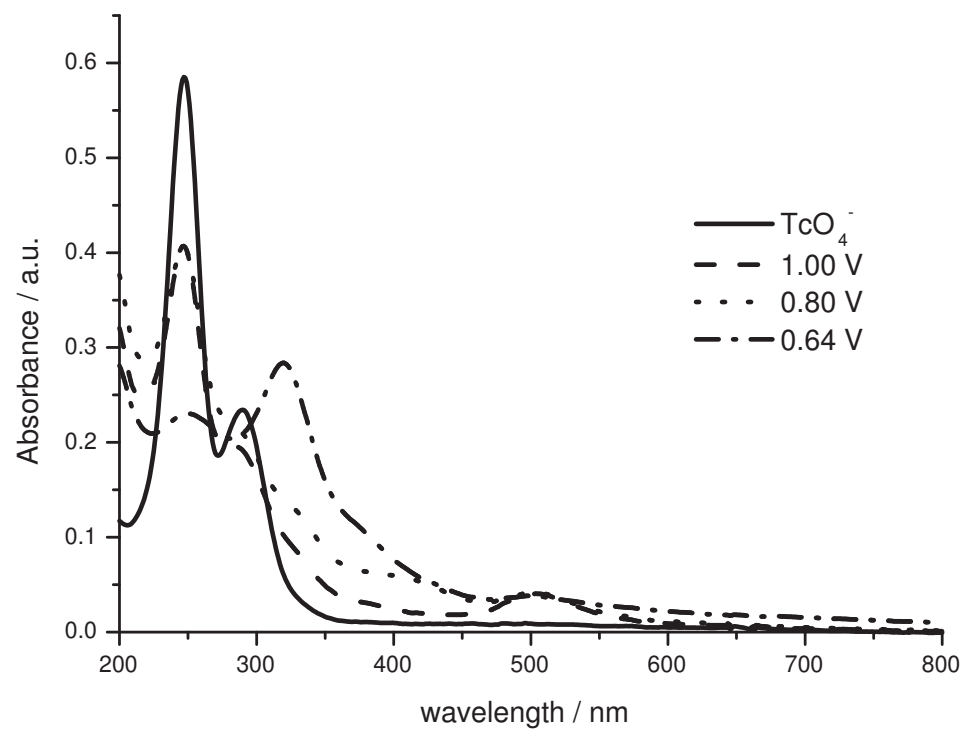

Fig. 3. UV-Vis spectra recorded after chronoamperometric polarization of RVCOTTLE in $0.5 \mathrm{mM} \mathrm{KTcO}_{4}+4 \mathrm{M} \mathrm{H}_{2} \mathrm{SO}_{4}$.

In the presence of nitric acid technetium(III/IV) ions are oxidized to technetium with higher than +IV oxidation states but not directly to pertechnetates. Observed changes in UV-Vis spectra are presented in Fig. 4. The maximum of the visible band at $502 \mathrm{~nm}$ shifts toward lower wavelengths. New technetium form is characterized spectroscopically by the band at $465 \mathrm{~nm}$ and could be indicative of the presence of $\mathrm{Tc}(\mathrm{V})$ in the electrolyte. Observed by Maslennikov et al [22] Tc(V) ions in the presence of nitric acid were characterized specrroscopically by the band with the maximum at $480 \mathrm{~nm}$. Noteworthly is the fact that this wave is broad and misshapen which suggest that apart from $\mathrm{Tc}(\mathrm{V})$ also some amounts of other Tc species can be formed in the presence of nitric acid. There are still some inconsistencies in description of this technetium ionic species. In nitric acid free concentrated sulfuric acid solution technetium(V) oxocations were described by the band at $695 \mathrm{~nm}$ [7]. 


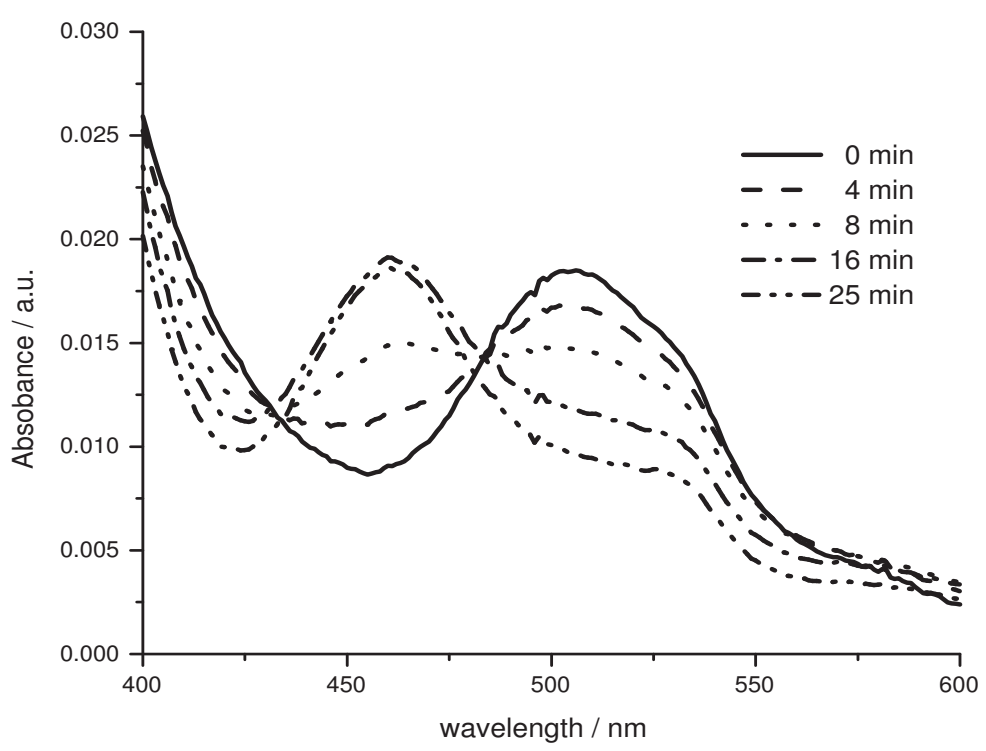

Fig. 4. Evolution of UV-Vis spectra of reduced technetium species in the presence of $\mathrm{HNO}_{3}$ in $4 \mathrm{M} \mathrm{H}_{2} \mathrm{SO}_{4}$.

\section{CONCLUSIONS}

The differences in electrocatalytic properties of gold, platinum and glassy carbon electrodes reveal during the reduction of pertechneatates in acidic media. Discussed process may lead to obain (depending on the experimental conditions) $\mathrm{Tc}(\mathrm{III}), \mathrm{Tc}(\mathrm{III}, \mathrm{IV})$ or $\mathrm{Tc}(\mathrm{IV})$ species. $\mathrm{TcO}^{2+}$ ions characterized spectroscopically by the band at $400 \mathrm{~nm}$ are much easier oxidized to pertechnetates than dimeric structures of Tc(III/IV), $\mathrm{Tc}_{2} \mathrm{O}_{2}{ }^{3+}$. $\mathrm{Tc}(\mathrm{V})$ species are probably generated as a product of $\mathrm{Tc}_{2} \mathrm{O}_{2}{ }^{3+}$ species oxidation by nitric acid. These ions absorb light at $465 \mathrm{~nm}$.

\section{REFERENCES}

[1] W. D. Loveland, D.J. Morrissey, G.T. Seaborg, „Modern Nuclear Chemistry", Wiley, 2006.

[2] D.A. Atwood (Ed), „Radionuclides in the environment”, Wiley, New York, 2010.

[3] J.A. Rard JA (Ed), „Chemical Thermodynamics of Technetium” Elsevier, New York, 1999.

[4] M. Chotkowski, A. Czerwiński, Electrochim Acta. 121, 44, (2014). 
[5] B. Pihlar, J. Electroanal. Chem.,102, 351, (1979).

[6] S. V. Kryuchkov, A. K. Pikaev, A. F. Kuzina and V. I. Spitsyn, Proc. Acad. Sci. USSR, Phys. Chem. Sect. (Engl. Trans.), 247, 690, (1979).

[7] F. Poineau, P. F. Weck, B. P. Burton-Pye, I. Denden, E. Kim, W. Kerlin, K. German, M. Fattahi, L. C. Francesconi, A. P. Sattelberger, K. R. Czerwinski, Dalton Trans. 42, 4348, (2013).

[8] F. Poineau, P. F. Weck, K. German, A. Maruk, G. Kirakosyan, W. Lukens, D. B. Rego, A. P. Sattelberger, K. R. Czerwinski, Dalton Trans. 39: 8616, (2010).

[9] M. Chotkowski, A. Czerwiński, Electrochim Acta. 76, 165, (2012).

[10] M. Chotkowski, A. Czerwiński, J. Radioanal. Nucl. Chem. 300, 229, (2014).

[11] E. Mausolf, F. Poineau, T. Hartmann, J. Droessler, K. Czerwinski, J. Electrochem. Soc. 158, E32, (2011).

[12] G. Horányi, I. Bakos, J. Electroanal. Chem., 370, 213, (1994).

[13] A. G. Maslennikov, O. Courson, V. E. Peretroukhine, F. David, M. Masson, Radiochim. Acta, 78, 123, (1997).

[14] M. Chotkowski, J. Radioanal. Nucl. Chem., DOI 10.1007/s10967015-4122-5 (2015).

[15] M. Chotkowski, Z. Rogulski, A. Czerwiński, J. Electroanal. Chem. 651, 237, (2011).

[16] S. Zamponi, M. DiMarino, A. Czerwiński, R. Marassi, J Electroanal Chem., 248, 341, (1988).

[17] S. Zamponi, A. Czerwiński, G. Gambini, R. Marassi, J Electroanal Chem., 332, 63, (1992).

[18] R.Woods, „Electroanalytical Chemistry”, (ed) A. J. Bard, vol. 9 Ch. 1, Marcel Dekker, 1976.

[19] S. Szabo, I. Bakos, J. Solid State Electrochem. 8, 190. (2004).

[20] N. Vongsouthi, M. Fattahi, B. Grambow (2006-2008) Subatech UMR 6457 Laboratoire de Physique Subatomique et des Technologies Associées, Scientific Report. http://www-subatech.in2p3.fr/Documents/SUBATECH2009.pdf.

[21] E. Mausolf, F. Poineau, J. Droessler, K. R. Czerwinski, J Radioanal Nucl. Chem. 288(3), 723, (2011).

[22] K. V. Rotmanov, A. G. Maslennikov, L. V. Zakharova, Yu. D. Goncharenko, V. F. Peretrukhin, Radiochem., 57(1), 26, (2015). 